\title{
Effect of circulating immune complexes on the binding of rheumatoid factor to histones
}

\author{
Hélène A Elicha Gussin, Katherine L Russo, Marius Teodorescu
}

\begin{abstract}
Objective-To determine whether the reaction of rheumatoid factor (RF) with solid phase histone is due to the simultaneous presence of circulating immune complexes (CICs) or aggregated IgG. Methods-Serum samples from 56 patients with seropositive rheumatoid arthritis (RA) and 50 random blood bank donors were used. Binding of immunoglobulins to histone was determined by enzyme linked immunosorbent assay (ELISA) and by western blots. Aggregated IgG was obtained by heating at $61^{\circ} \mathrm{C}$ for 30 minutes.
\end{abstract}

Results-Among the RA sera tested by ELISA, 54\% were positive for histone binding by IgM, IgG, or IgA and $20 \%$ by IgM only. Heating of normal sera caused a significant enhancement in the binding of IgG to histone $(p<0.001)$. This binding had a non-cognate behaviour-that is, it was destroyed by pepsin treatment of serum and was not significantly inhibited by competition with free histone. The same behaviour was seen for IgM, IgG, and IgA binding from RA sera. However, cognate IgG antibody binding to histone was inhibited by free histone and was resistant to pepsin digestion. Addition of heat aggregated IgG to RA sera or pretreatment of histone with aggregated IgG caused a significant increase in IgM binding to histone.

Conclusion-IgM, IgG, and IgA RF bind to solid phase histone as a result of attachment to histone of immune complexes or aggregated IgG and not as a result of a cognate reaction with histone.

(Ann Rheum Dis 2000;59:351-358)

Histones are highly conserved polycationic proteins that bind to the eukaryotic DNA; in cell nuclei, histones and DNA are organised into nucleosomes, ${ }^{12}$ which are extruded from cells undergoing apoptosis. ${ }^{34}$ From results of studies using enzyme linked immunosorbent assays (ELISA), some patients appear to have rheumatoid factors (RFs) with the ability to recognise histones. ${ }^{5}$ Such binding has also been shown for a mouse monoclonal RF (IgM isotype). ${ }^{7}$ However, it has never been shown that binding of RF from patient sera to histone is cognate. In fact, attempts to use free histone as a soluble competitor for the binding of monoclonal IgM RF to histone have failed; this failure has been attributed to the peculiar character of molecular interactions between histones. ${ }^{7}{ }^{8}$ Here we evaluate to what extent the apparent binding of serum $\operatorname{Ig} M, \operatorname{IgG}$, or $\operatorname{Ig} A$ $\mathrm{RF}$ to histone is actually the result of a primary capture of aggregated IgG, or circulating immune complexes (CICs) from the serum sample by the solid phase histone and the subsequent cognate interaction of $\mathrm{RF}$ with the captured IgG.

\section{Materials and methods}

PATIENT SPECIMENS

Serum specimens were obtained from the serum collection of the Rheumatology/ Immunology Laboratory, University of Illinois at Chicago Medical Centre. The specimens used in this study had been stored for three years or less at $-20^{\circ} \mathrm{C}$ and derived from excess serum from patient blood samples collected for routine laboratory tests. The serum samples were thawed once, $0.02 \%$ sodium azide was added, and they were maintained at $4^{\circ} \mathrm{C}$ for as long as two months. Four specimens were not frozen (identified as R11, R12, R14, and R15); they were stored at $4^{\circ} \mathrm{C}$ for up to three weeks. None of the samples contained any precipitates or visible aggregates. Sera that contained high levels of all three isotypes of rheumatoid factors (EL-RF/3-IgM-IgG-IgA kits, TheraTest Laboratories, Inc, Chicago, IL) ${ }^{9}$ were selected from 56 patients with RA. Control sera were obtained from 50 random blood bank donors and from two patients with systemic lupus erythematosus with high levels of antihistone IgG (2500 U/ml, normal limit $96 \mathrm{U} / \mathrm{ml}$; EL-ANA/8 kit, TheraTest/ DiaSorin, DiaSorin, Stillwater, $\mathrm{MN}$ ).

HISTONE AND OTHER NUCLEAR ANTIGENS.

Bovine thymus histone, which contained $\mathrm{H} 1$, $\mathrm{H} 2 \mathrm{~A}, \mathrm{H} 2 \mathrm{~B}, \mathrm{H} 3$, and $\mathrm{H} 4$, was obtained from Roche/Boehringer-Mannheim Corporation (Indianapolis, IN) and checked for protein contaminants by sodium dodecyl sulphatepolyacrylamide gel electrophoresis (SDSPAGE), as described below.

Calf thymus DNA (stored frozen $1 \mathrm{mg} / \mathrm{ml}$ in water), purchased from Pharmacia (Pharmacia Biotech Inc, Piscataway, NJ), was denatured by boiling for 10 minutes and then diluted in phosphate buffered saline (PBS) for a final concentration of denatured DNA (ssDNA) of $10 \mu \mathrm{g} / \mathrm{ml}$. Immunoaffinity purified bovine $\mathrm{nRNP} / \mathrm{Sm}(200 \mathrm{U} / 0.2 \mathrm{ml})$ was obtained from ImmunoVision Inc, Springdale, AR.

\section{IMMUNOGLOBULINS}

ChromPure whole human IgG was purchased from Jackson ImmunoResearch Laboratories, West Grove, PA. Absence of contaminating proteins in the samples was verified from 
patterns obtained by reducing SDS-PAGE and Coomassie blue staining.

HEAT AGGREGATION OF IGG

Heat aggregation of serum or purified $\operatorname{IgG}^{10}$ was performed by incubation of the samples in a water bath at $61^{\circ} \mathrm{C}$ for 30 minutes, before diluting them in the appropriate buffer. The samples subjected to this process showed no evidence of turbidity.

\section{PEPSIN DIGESTION OF IMMUNOGLOBULINS IN} SERUM

Pepsin treatment of sera, which destroys IgM and leaves functional the $\operatorname{IgA}$ and $\mathrm{F}\left(\mathrm{ab}^{\prime}\right)_{2}$ portion of IgG, was performed as described previously. ${ }^{9}$ Ten microlitres of each serum specimen was diluted in $0.5 \mathrm{ml}$ of a solution of $9 \mu \mathrm{g} / \mathrm{ml}$ pepsin, and then incubated at $37^{\circ} \mathrm{C}$ for 18-24 hours. Thereafter, the pepsin was inactivated by addition of $0.5 \mathrm{ml}$ of a phosphate buffer plus $0.05 \%$ Tween 20 (Fisher Scientific, Fair Lawn, NJ). For non-digested controls, $10 \mu \mathrm{l}$ of each serum specimen was incubated in parallel in $0.5 \mathrm{ml}$ of a solution that did not contain pepsin.

PREPARATION OF SERUM SAMPLES FOR USE IN A COMPETITIVE INHIBITION ASSAY

Samples of $10 \mu \mathrm{l}$ of serum were mixed with 10 $\mu \mathrm{l}$ of total histone solution $(10 \mathrm{mg} / \mathrm{ml})$, or with $10 \mu \mathrm{l}$ PBS (control). After a one hour incubation of the mixture at room temperature, $980 \mu \mathrm{l}$ of PBS with $0.05 \%$ Tween 20 (PBST) was added for a final sample dilution of 1/100.

COATING OF ANTIGENS TO PLASTIC

Before their use for coating ELISA plate wells, histones and other antigens were diluted in PBS to obtain a final antigen concentration of $10 \mu \mathrm{g} / \mathrm{ml}$. Into each antigen well (Immulon-4, Dynex Technologies Inc, Chantilly, VA), $100 \mu \mathrm{l}$ of antigen solution was dispensed (histone, $\mathrm{nRNP} / \mathrm{Sm}$, or ssDNA). The plates were incubated at $20-22^{\circ} \mathrm{C}$ (room temperature) for 18-20 hours and then the antigen solution was discarded. The antigen coated wells were further incubated with $200 \mu$ l of Stabilcoat (Surmodics, Eden Prairie, MN) for one hour. An equal number of wells were incubated with $200 \mu$ of Stabilcoat only (no antigen) for one hour and were used as specimen blanks. After discarding the Stabilcoat solution, all plates were desiccated for three hours and then sealed with a desiccant in metallised pouches. The plates were stored at $4^{\circ} \mathrm{C}$ and used within 60 days.

When the specificity of the histone coated wells was tested they were found to react strongly with sera containing high levels of antihistone antibodies. However, sera with relatively high levels of antibodies directed against nuclear antigens other than histone (nRNP/Sm, nRNP, SSA, SSB, Scl70, DNA) showed reactivity with their respective cognate antigens but not with histones.

ELISA TESTING PROCEDURE

With the exception of the antigen coated plates, all reagents used were from commercial clinical laboratory diagnostic kits (EL-ANA Profiles, DiaSorin/TheraTest kits, DiaSorin Inc, Stillwater, $\mathrm{MN}$, unless otherwise specified). The EL-ANA profile kits were used to measure the binding of IgG to ssDNA (denatured), dsDNA, Sm, nRNP/Sm complex, SSA, SSB, Scl70, and histone. For each antigen coated well used during an assay, one well coated with Stabilcoat only was used as its corresponding specimen blank. Serum specimens were diluted 1:100 (unless otherwise stated) in the specimen diluent containing Tween 20, and $100 \mu \mathrm{l}$ aliquots of the diluted specimens were added with multichannel pipettes into the wells. After the plates had been incubated at room temperature for 30 minutes (binding of primary antibody), they were washed three times with the wash solution and then $100 \mu \mathrm{l}$ of horse radish peroxidase-antibody conjugate solution was added to each well. Horse radish peroxidase-antibody conjugate was either goat antihuman IgG (Fc $\gamma$ chain specific) antibody (EL-ANA/8), rabbit antihuman $\mathrm{F}\left(\mathrm{ab}^{\prime}\right)_{2}$, rabbit antihuman $\operatorname{IgM}\left(\mathrm{Fc}_{54}\right)$, or rabbit antihuman IgA antibody (EL-RF/3). After an additional 30 minutes' incubation of the plates (conjugate binding) at room temperature, the wells were washed and the chromogen-substrate solution (3,3',5,5'-tetramethylbenzidine) was added. After a 15 minute incubation period, the reaction was stopped with $1 \mathrm{M}$ phosphoric acid. The absorbance values at $450 \mathrm{~nm}$ of wells $\left(\mathrm{A}_{450}\right)$ were read with an ELISA plate reader interfaced to a computer. Net absorbance was calculated by subtracting the $\mathrm{A}_{450}$ of the specimen blank well from the $\mathrm{A}_{450}$ of the corresponding antigen coated wells (the blank values did not exceed an $\mathrm{A}_{450}$ of 0.15 ). All tests were performed in duplicate or triplicate.

The enzyme conjugates were tested at the working dilution for their reaction with the antigen coated wells; in no case did the raw $\mathrm{A}_{450}$ exceed 0.1 .

ELISA TESTING FOR C1Q BINDING

Tests for binding of CICs to $\mathrm{C} 1 \mathrm{q}$ were performed with an ELISA CIC-C1q kit (Quidel Corporation, San Diego, CA), according to the manufacturer's instructions; absorbance values were read at $405 \mathrm{~nm}\left(\mathrm{~A}_{405}\right)$.

\section{POLYACRYLAMIDE GELS AND WESTERN BLOTS}

SDS-PAGE was performed in a $12.5 \%$ gel in Tris/glycine/SDS buffer at constant current (15 $\mathrm{mA}$ ). After migration, proteins in the gel were stained in parallel by Coomassie blue or silver (Silver Stain Plus, BioRad, Hercules, CA).

For western blots, $10 \mu \mathrm{l}$ of histone (mix of $10 \mu \mathrm{l}$ of each of $\mathrm{H} 1, \mathrm{H} 2 \mathrm{~A}, \mathrm{H} 2 \mathrm{~B}, \mathrm{H} 3$, and $\mathrm{H} 4$ ) were subjected to SDS-PAGE. After overnight transfer onto a nitrocellulose membrane the bands were developed with the help of the Immun-Blot horse radish peroxidase assay kit, that uses horse radish peroxidase-conjugated antihuman $\operatorname{IgG}(\mathrm{H}+\mathrm{L}$ chains $)$ goat antibody as the secondary antibody, according to the manufacturer's instructions (BioRad Laboratories, Hercules, CA). 
STATISTICS

Statistical significance of differences between sets of absorbance values was determined with the Kolmogorov-Smirnov test (StatWorks, Cricket Software Inc, Philadelphia, PA). The agreement $(\kappa)$ was calculated with the help of the web site for applied statistics (http://maddog. fammed.wisc.edu/ rbrown/epi.html). For categorical data, differences between groups were evaluated by $\chi^{2}$, and $p$ values were obtained from tables. ${ }^{11}$

\section{Results}

BINDING TO HISTONE COATED PLATES OF IGM, IGG, AND IGA FROM RA SERUM SAMPLES

From our serum collection, 56 RA serum samples containing abnormal levels of $\operatorname{IgM}, \mathrm{IgG}$, and IgA RF were tested for binding of major isotypes of immunoglobulin to histone coated plates. The reactions were developed with goat antihuman $\operatorname{IgG}(\mathrm{Fc} \gamma)$, rabbit antihuman $\operatorname{IgM}$ $\left(\mathrm{Fc}_{54}\right)$, or rabbit antihuman IgA enzymeantibody conjugates. As controls, we used (a) serum samples from two patients with systemic lupus erythematosus who had high levels of antihistone IgG antibody $(2500 \mathrm{U} / \mathrm{ml}$; normal $96 \mathrm{U} / \mathrm{ml})$, (b) heat treated normal human serum containing aggregated $\operatorname{IgG}$, and (c) specimens from 50 random blood bank donors.

The average net $\mathrm{A}_{450}$ (SD) yielded by the serum samples from blood bank donors was

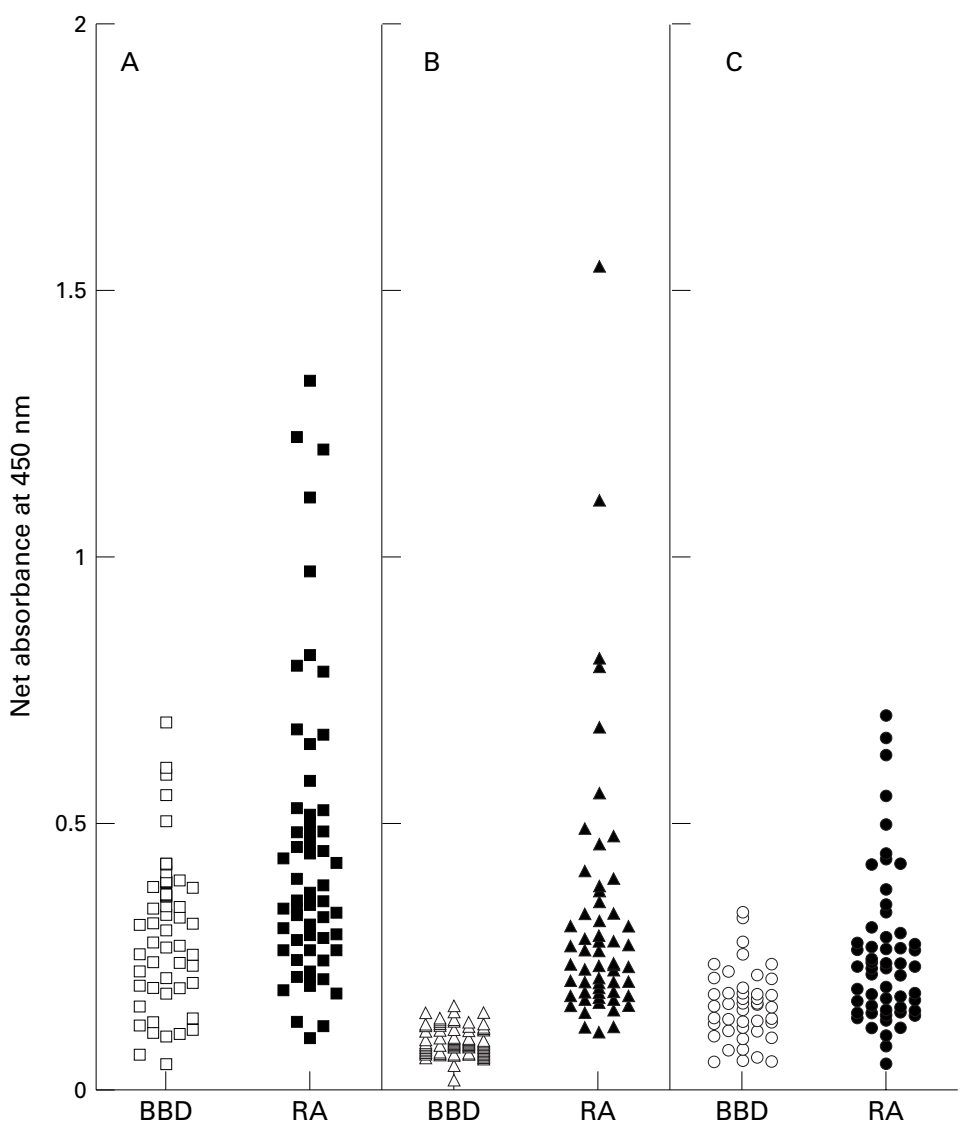

Figure 1 Reaction with solid phase histone of immunoglobulin from control and RA sera. Scattergram of the net $A_{450}$ values yielded by ELISA on histone coated wells, reacted with sera from 50 blood bank donors (BBD, open symbols) and 56 patients with rheumatoid arthritis (RA, solid symbols). Enzyme-conjugate was isotype-specific anti-IgM $(A)$, anti-IgG $(B)$, or anti-IgA $(C)$.
Table 1 Effect of heating on the binding to solid phase histone of IgG. Net $A_{450}$ yielded by ELISA on histone coated wells reacted with purified human IgG and 10 blood bank donor (BBD) serum samples, incubated at $20^{\circ} \mathrm{C}$ or at $61^{\circ} \mathrm{C}$ (aggregation). Conjugate is goat antihuman $\operatorname{IgG}$ $(F c \gamma)$-horse radish peroxidase

\begin{tabular}{lll}
\hline & \multicolumn{2}{l}{ Temperature of incubation } \\
\cline { 2 - 3 } Specimen number & $20^{\circ} \mathrm{C}$ & $61^{\circ} \mathrm{C}$ \\
\hline Purified IgG & 0.250 & 1.800 \\
BBD1 & 0.058 & 1.722 \\
BBD2 & 0.136 & 1.096 \\
BBD3 & 0.043 & 1.833 \\
BBD4 & 0.089 & 1.792 \\
BBD5 & 0.164 & 2.993 \\
BBD6 & 0.108 & 2.775 \\
BBD7 & 0.115 & 2.880 \\
BBD8 & 0.087 & 3.229 \\
BBD9 & 0.033 & 3.036 \\
BBD10 & 0.116 & 3.112 \\
\hline
\end{tabular}

$0.29(0.10)$ for $\operatorname{IgM}, 0.10(0.05)$ for $\operatorname{IgG}$, and 0.15 (0.09) for IgA (fig 1). We considered the average normal net $\mathrm{A}_{450}+3 \mathrm{SD}$ to be the upper limit of normal. On the basis of these upper limits, 54\% (30/56) of the RA patient sera had abnormal values of binding of at least one immunoglobulin isotype to the histone coated wells, with the following distribution: IgM $20 \%$ (11/56); IgG 43\% (24/56); IgA 20\% (11/56). The difference between the reaction with histone coated plates of sera from blood bank donors and sera from patients with RA was significant $(p<0.05$ for IgM; $p<0.005$ for IgG; $\mathrm{p}<0.02$ for IgA, Kolmogorov-Smirnov). There was no correlation between the levels of $\operatorname{IgM}$, IgG, and IgA RF and the ability to bind histone (data not shown). Thus immunoglobulins from a relatively large proportion of the seropositive patients with RA studied bound to solid phase histones. However, these results do not deal with the question of the nature of immunoglobulin binding to the histone coated wells.

EFFECT OF IGG AGGREGATION ON THE REACTION OF IGM RHEUMATOID FACTOR WITH HISTONES

Binding to histone coated plates of IgG from heated serum and of IgG from non-heated serum was compared for specimens from 10 blood bank donors. There was a significant increase in the net $\mathrm{A}_{450}$ yielded by heated serum samples compared with the non-heated samples when the enzyme conjugate used for development was IgG specific (table 1) $(\mathrm{p}<0.001$, Kolmogorov-Smirnov). Essentially the same results were obtained with purified normal human IgG (table 1) - that is, heat aggregation of purified IgG resulted in a significant increase of the net $\mathrm{A}_{450}$ value yielded by the ELISA developed with isotype-specific anti-IgG relative to the value obtained with non-aggregated IgG. Thus heat aggregation of normal IgG increased its avidity for solid phase histone.

The binding of IgG from heated normal serum was determined on wells coated by nine nuclear antigens: ssDNA (denatured), dsDNA, Sm, nRNP/Sm complex, SSA, SSB, Scl70, and histone. The $\mathrm{A}_{450}$ values obtained were respectively: $0.06,0.08,0.07,0.10,0.03,0.07,0.02$, and 2.8 -that is, the histone reaction was highly abnormal and the reaction with all other 
nuclear antigens was within normal limits. Thus heat aggregated IgG did not bind to any other known nuclear antigens that could potentially contaminate the histone preparation used in these experiments. On the other hand, sera with high levels of antibodies (with reactions $>20$ times the upper limit of normal with their respective antigen coated wells) directed against ssDNA, ssDNA and dsDNA, Sm and nRNP, nRNP, SSA, SSB, and Scl70 showed reactions within normal limits with the histone coated wells. Thus the histone used in these reactions was not significantly contaminated with other nuclear antigens and it is most likely the target of binding of IgG aggregates.

The effect of heat treatment of serum on the apparent binding to histone of serum $\operatorname{IgM}$ was determined for 10 normal and $10 \mathrm{RA}$ serum samples. A small, but nevertheless significant, increase in IgM binding occurred when normal sera were heated (mean value increased from 0.092 to $0.235 ; \mathrm{p}=0.002$, KolmogorovSmirnov; fig 2A). However, when the RA sera were heated, there was a substantial and significant increase in the apparent binding of IgM to histones (mean value from 0.304 to 1.215 ; $\mathrm{p}<0.001$, Kolmogorov-Smirnov; fig 2B). There was essentially no increase in the binding of IgM from RA sera when the same experiment was performed with ssDNA and $\mathrm{nRNP} / \mathrm{Sm}$ instead of histone (fig $2 \mathrm{~B}$, lanes 5, 6).

The effect of heat treatment of serum on the apparent binding to histone of $\operatorname{IgM}$ from patient serum, together with the finding that aggregated IgG binds to solid phase histone, suggested that aggregated IgG became attached to histone and functioned as an antigen for IgM RF. Thus histone coated wells and blank wells were treated for 30 minutes at room temperature with either heated or non-heated normal serum and were washed three times with PBST. Two dilutions, $1: 100$ and 1:1000, of an RA serum containing high levels of RF were tested on these pretreated wells. Heated

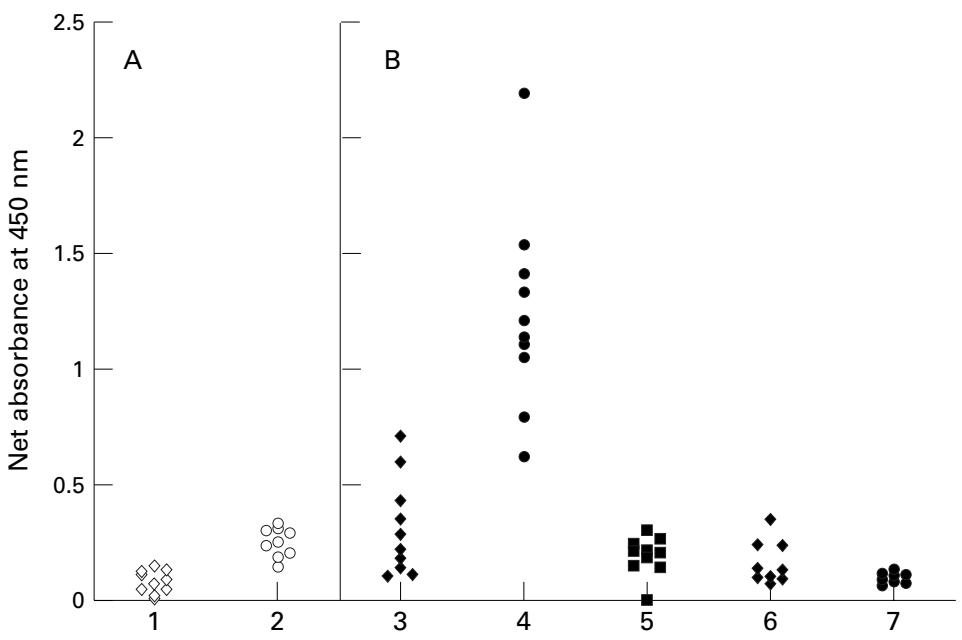

Figure 2 Effect of serum heating at $61^{\circ} \mathrm{C}$ on the binding of IgM RF from $R A$ sera to histone and to other nuclear antigens. Scattergram of the net $A_{450}$ yielded on ELISA by serum samples from blood bank donors $(A)$ and patients with rheumatoid arthritis sera (B): non-heated $(1,3)$ or heated at $61^{\circ} \mathrm{C}$ for 30 minutes $(2,4,5,6,7)$. Wells were coated with histones (1-4), ssDNA (5), $n R N P / S m$ (6) or were blanks (7, raw $A_{450}$ ).

Isotype-specific enzyme-conjugate was anti-IgM.

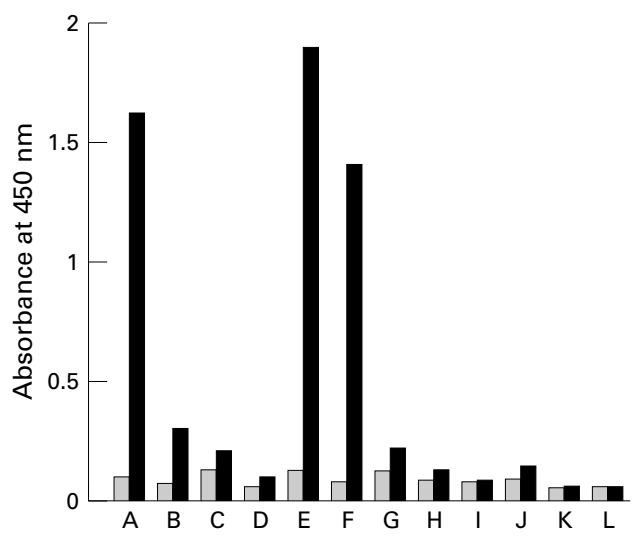

Figure 3 Effect of the pretreatment of histone coated wells with aggregated serum IgG on the binding to histone of IgM from RA sera. $A_{450}$ yielded by blank plates (shaded bars) and by wells coated with histone (solid bars) of normal serum heated at $61^{\circ} \mathrm{C}$ for 30 minutes $(A, B)$; non-heated $R A$ serum $(C, D) ; R A$ serum on wells preincubated for 30 minutes with heated normal serum (E, $F)$ or non-heated normal serum $(G, H)$; and by non-heated normal serum $(I, \mathcal{F})$, and enzyme conjugates $(K, L)$ as controls. $R A$ serum was diluted $1 / 100(C, E, G)$, or $1 / 1000(D, F, H)$. Reactions were shown with isotype-specific enzyme-antibody conjugates: goat antihuman $F_{c \gamma} \gamma$ chain-specific lanes $\left.A, I, K\right)$, or rabbit antihuman $F_{S_{\mu \mu}}$ (lanes $B, C, D, E, F, G, H, \mathcal{F}, L$ ) antibodies.

normal serum was used as a control (fig 3, A and B). There was a significant increase in the binding of IgM from RA serum when histone coated wells were pretreated with heat aggregated IgG $(\mathrm{p}<0.05)$; non-heated IgG had no effect (fig 3, $\mathrm{E}$ and $\mathrm{F} v \mathrm{G}$ and $\mathrm{H}$ ). The enhancement of IgM binding to histone coated wells by pretreatment with aggregated IgG was reproduced in tests of 10 additional RA sera (table 2). Thus IgM from RA serum, probably rheumatoid factor, appears to bind aggregates of IgG captured by the solid phase histone.

REACTION WITH HISTONE COATED WELLS OF RF IN SERUM SAMPLES CONTAINING AGGREGATED IGG OR IMMUNE COMPLEXES

A normal serum was heat treated and mixed at a constant concentration with increasing concentrations of RA serum; a parallel set of control samples was prepared with the same normal serum which had not been heat treated. The binding to histone coated wells of IgG and of IgM from these serum mixes was then

Table 2 Effect of preincubation of histone coated ELISA wells with aggregated normal IgG on the binding of IgM rheumatoid factor from rheumatoid arthritis (RA) serum samples. Reaction (net $A_{450}$ ) from $10 \mathrm{RA}$ serum samples with histone coated wells and histone coated wells preincubated with heated normal serum; enzyme-conjugate is rabbit antihuman $\operatorname{IgM}\left(\mathrm{FC}_{\left.\mathrm{S}_{1}\right)}\right)$-horse radish peroxidase. Values are mean (SD)

\begin{tabular}{lll}
\hline $\begin{array}{l}\text { RA specimen } \\
\text { number }\end{array}$ & Histone coated wells & $\begin{array}{l}\text { Histone coated wells } \\
\text { and heated normal } \\
\text { serum }\end{array}$ \\
\hline R1 & $0.420(0.017)$ & $1.801(0.035)$ \\
R2 & $0.173(0.009)$ & $1.779(0.045)$ \\
R3 & $0.138(0.020)$ & $1.818(0.075)$ \\
R4 & $0.583(0.025)$ & $1.245(0.050)$ \\
R5 & $0.338(0.015)$ & $1.960(0.032)$ \\
R6 & $0.275(0.028)$ & $1.616(0.040)$ \\
R7 & $0.689(0.035)$ & $1.974(0.014)$ \\
R8 & $0.102(0.011)$ & $2.100(0.045)$ \\
R9 & $0.150(0.017)$ & $1.904(0.050)$ \\
R10 & $0.214(0.008)$ & $1.249(0.020)$ \\
\hline
\end{tabular}




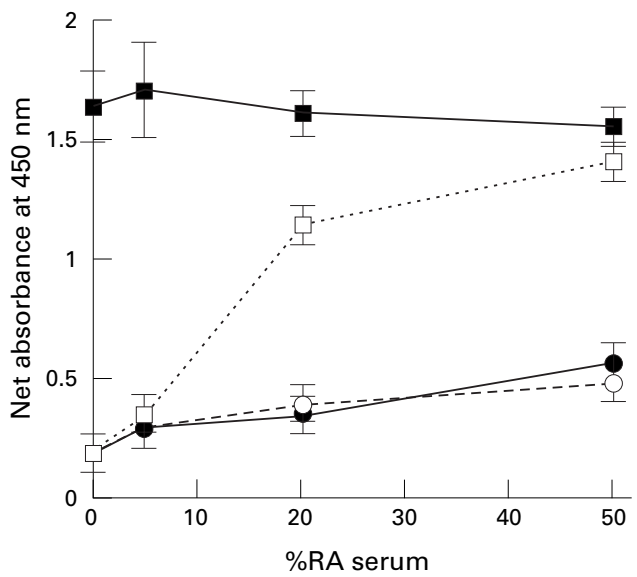

Figure 4 Effect of addition of heat aggregated serum IgG to $R A$ serum on the binding to histone of IgM. Net $A_{450}$ (SD) yielded by mixtures of $R A$ serum and non-heated normal serum (circles), and $R A$ serum and heated normal serum (squares). The proportion of $R A$ serum in the mix was variable ( $\% R A$ serum). Binding was shown by anti-IgG enzyme-conjugate (solid symbols, solid line) or anti-IgM (open symbols, dashed line).

determined. Heating the normal serum before its addition to RA serum caused a significant increase in the binding of $\operatorname{IgM}$ to the histone coated wells (fig 4). Thus the presence of aggregated IgG in serum provided an antigenic substrate for the binding of IgM RF to the histone coated wells. However, the order of the reaction among reactants is not addressed by this experiment.

THE NATURE OF INTERACTION OF RF WITH HISTONE ON THE SOLID PHASE

The possibility that Fc $\gamma$ played a part in the binding of aggregated IgG or CICs was considered; pepsin was used to break down Fc $\gamma$ into $\mathrm{pFc}$ fragments. However, at the same time

Table 3 Reaction (net $A_{450}$ ) with histone of serum samples containing true antihistone IgG antibody (HS-1, HS-2) of heat aggregated normal serum (heated NS) and of serum samples from patients with $R A^{\star}$ (R11-R27)

\begin{tabular}{|c|c|c|c|c|c|}
\hline \multirow[b]{3}{*}{ Specimens } & \multicolumn{5}{|c|}{ Enzyme conjugate specificity } \\
\hline & \multirow[b]{2}{*}{ 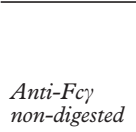 } & \multicolumn{2}{|c|}{$\begin{array}{l}\text { Anti-F(ab') }{ }_{2} \text { (detects IgG and } \\
\operatorname{IgM})\end{array}$} & \multicolumn{2}{|c|}{ Anti-IgA a chain } \\
\hline & & Non-digested & $\begin{array}{l}\text { Pepsin } \\
\text { digested }\end{array}$ & Non-digested $t$ & $\begin{array}{l}\text { Pepsin } \\
\text { digested } t\end{array}$ \\
\hline HS-1 & 1.25 & 1.50 & 1.43 & 0.07 & 0.00 \\
\hline HS-2 & 1.00 & 1.74 & 1.68 & NA & 0.00 \\
\hline Heated NS & 1.85 & 1.47 & 0.03 & 0.69 & 0.00 \\
\hline $\mathrm{R} 11$ & NA & 1.24 & 0.03 & NA & 0.05 \\
\hline $\mathrm{R} 12$ & 1.20 & 1.16 & 0.06 & 0.69 & 0.00 \\
\hline R13 & NA & 0.85 & 0.00 & NA & 0.00 \\
\hline R14 & 0.91 & 1.36 & 0.01 & NA & 0.00 \\
\hline R15 & NA & 1.17 & 0.10 & NA & 0.00 \\
\hline R16 & 0.47 & 1.56 & 0.08 & 0.55 & 0.00 \\
\hline $\mathrm{R} 17$ & 0.45 & 0.69 & 0.09 & 0.35 & 0.00 \\
\hline $\mathrm{R} 18$ & 0.39 & 0.64 & 0.05 & NA & 0.00 \\
\hline R19 & 0.35 & 1.25 & 0.09 & NA & 0.00 \\
\hline R20 & 0.88 & 1.23 & 0.00 & 0.40 & 0.02 \\
\hline R21 & 0.45 & 0.70 & 0.07 & NA & 0.05 \\
\hline R22 & NA & 0.93 & 0.08 & 0.39 & 0.02 \\
\hline R23 & 0.44 & 0.95 & 0.09 & 0.41 & 0.00 \\
\hline $\mathrm{R} 24$ & 0.58 & 0.77 & 0.05 & 0.34 & 0.00 \\
\hline R25 & NA & 1.08 & 0.05 & 0.67 & 0.03 \\
\hline R26 & 0.46 & 1.55 & 0.02 & 0.43 & 0.01 \\
\hline R27 & 0.83 & 0.95 & 0.11 & NA & 0.01 \\
\hline
\end{tabular}

${ }^{\star}$ Specimens were selected if the $\mathrm{A}_{450}$ with anti-Fc $\gamma$ was $>0.35$ or if the $\mathrm{A}_{450}$ with anti-IgM or antiIgA was above the upper limit of normal.

+Under the same conditions, using rabbit IgG as an antigen, the reduction due to pepsin digestion was less than $15 \%$ - that is, the IgA was pepsin resistant.

$\mathrm{NA}=$ not applicable (when $\mathrm{A}_{450}$ was within normal range). that pepsin degrades $\mathrm{Fc} \gamma$, it also destroys the binding function of $\operatorname{IgM},{ }^{9}$ so that $\operatorname{IgM} \mathrm{RF}$ would not be detectable in serum samples treated with pepsin. Nevertheless, IgG and IgA $\mathrm{RF}$, as well as cognate binding of IgG and IgA, could still be measured after pepsin digestion. Thus the RA sera were incubated with pepsin or, as a control, with only the pepsin digestion buffer at $37^{\circ} \mathrm{C}$ for 18 hours. These RA serum samples were incubated with histone coated wells and the binding of $\operatorname{IgG}$ and $\operatorname{IgA}$ was measured with anti-F(ab') $)_{2}$ and anti-IgA enzyme conjugates, respectively (table 3 ). The extent of the reduction in the $\mathrm{A}_{450}$ for pepsin digested specimens, obtained with anti- $\mathrm{F}\left(\mathrm{ab}^{\prime}\right)_{2}$ and with anti-IgA, as compared with controls, was taken as an indication of the sensitivity of IgG to pepsin digestion. The cognate binding of IgG was only slightly reduced (by $5-15 \%$ ) (table 3, specimens HS-1 and HS-2), whereas the binding of the heat aggregated IgG was completely abolished $\left(\mathrm{A}_{450}\right.$ decreased from 1.47 to 0.03) (table 3, heated NS). Like the heat aggregated IgG, pepsin treatment reduced significantly (by 95-100\%) the binding to histone coated wells of IgG and IgA in sera from all RA specimens tested. However, pepsin digestion did not affect the IgA and IgG RF activity for their cognate antigen, rabbit IgG (table 3); the same behaviour was seen for specimens R12, R14, and R15, which were not stored frozen. Thus the IgG and IgA RF binding to histone was most likely non-cognate, the result of attachment of CICs concomitantly present in the RA serum.

Free histone was expected to inhibit poorly the non-cognate binding of CICs and, as a consequence, of RF. Indeed, the cognate binding of IgG was markedly reduced by competition with free histones (by an average of $92 \%$ ) (table 4, specimens HS-1 and HS-2), whereas the binding of heat aggregated normal IgG and IgA was only slightly reduced (by $16 \%$ and $18 \%$ respectively) (table 4 , heated NS). Free histone inhibited only slightly the binding of IgM, IgG, and IgA RF from RA sera; the average inhibitions were $20 \%, 20 \%$, and $2 \%$ respectively (table 4); the same behaviour was seen for specimens R11, R12, R14, and R15, which were not stored frozen. Thus the binding to histones of RF from RA sera had a non-cognate behaviour-that is, it was dependent on the interaction of CICs with histone to provide an antigenic substrate.

The effect of pepsin digestion on the binding of IgG to histones was also investigated by western blots. Individual histones were first analysed by polyacrylamide gel electrophoresis. The histones and their components $(\mathrm{H1}$, $\mathrm{H} 2 \mathrm{~A}, \mathrm{H} 2 \mathrm{~B}, \mathrm{H} 3$, and $\mathrm{H} 4$ ), showed major bands on polyacrylamide gel electrophoresis at their respective (approximate) molecular weight positions of $21,14,13,15$, and $11 \mathrm{kDa}$, respectively. $\mathrm{H} 1$ showed discrete bands at a molecular weight below its expected position, probably the result of minor protein fragmentation (data not shown). $\mathrm{H} 3$ was slightly contaminated with H1 (data not shown). For western blots (fig 5) we used prestained molecular weight standards and a mix of all histone proteins (lane 1), H2A 
Table 4 Inhibition of binding to solid phase histone by free histone: differences between antibodies and the immunoglobulins from rheumatoid arthritis patient serum samples

\begin{tabular}{|c|c|c|c|}
\hline \multirow[b]{2}{*}{ Specimen } & \multicolumn{3}{|c|}{$\begin{array}{l}\text { \% Inhibition with free histone as detected by } \\
\text { enzyme conjugates specific for }\end{array}$} \\
\hline & $F c \gamma$ & $F c_{5 \mu}$ & Ig $A$ a chain \\
\hline $\mathrm{HS}-1^{\star}$ & 96 & NA & NA \\
\hline $\mathrm{HS}-2^{\star}$ & 89 & NA & NA \\
\hline Heated NS & 16 & NA & 18 \\
\hline $\mathrm{R} 11$ & NA & 16 & NA \\
\hline $\mathrm{R} 12$ & 19 & NA & $0^{c}$ \\
\hline R13 & NA & 23 & NA \\
\hline $\mathrm{R} 14$ & 18 & 22 & NA \\
\hline R15 & NA & 4 & NA \\
\hline R16 & 25 & 21 & $0^{\mathrm{c}}$ \\
\hline $\mathrm{R} 17$ & 15 & NA & $0^{c}$ \\
\hline R18 & 8 & NA & NA \\
\hline R19 & 11 & 31 & NA \\
\hline R20 & 46 & $0^{c}$ & $0^{c}$ \\
\hline R21 & 0 & NA & NA \\
\hline $\mathrm{R} 22$ & NA & 10 & $0^{c}$ \\
\hline R23 & 25 & NA & $0^{c}$ \\
\hline $\mathrm{R} 24$ & 36 & NA & $0^{c}$ \\
\hline R25 & NA & 31 & $0^{c}$ \\
\hline R26 & 20 & 40 & 20 \\
\hline $\mathrm{R} 27$ & 15 & NA & NA \\
\hline Average for RA & 20 & 20 & 2 \\
\hline
\end{tabular}

${ }^{\star}$ HS-1 and HS-2 are histone-specific patient serum samples. $0^{c}$ slight enhancement was taken as 0 .

$\mathrm{NA}=$ not applicable (when $\mathrm{A}_{450}$ was within normal range).

and $\mathrm{H} 2 \mathrm{~B}$ only (lane 2), and $\mathrm{H} 3$ and $\mathrm{H} 4$ (lane $3)$. The following specimens were reacted with the blotted membrane and developed with an enzyme-conjugate specific for human IgG heavy and light chains: normal serum, heated or not, spiked serum HS-1 (diluted to obtain an absorbance in ELISA similar to that seen with RA sera) and RA serum R27, containing IgG with histone binding activity. For each specimen we tested a pepsin digested aliquot and an aliquot incubated in the digestion buffer. The binding of IgG in heated serum (fig 5, panel A) and in RA serum (fig 5, panel C) were visible, mainly $\mathrm{H} 1, \mathrm{H} 3$, and $\mathrm{H} 4 ; \mathrm{H} 2 \mathrm{~A}$ and $\mathrm{H} 2 \mathrm{~B}$ were only lightly stained. All of these bands disappeared entirely when the specimens were digested with pepsin (fig 5, panels B and D). On the other hand, the reactivity with histone of true antihistone IgG to histone on the nitrocellulose membrane was not affected by the pepsin digestion - that is, the digested and undigested samples yielded similar bands (fig 5, panels $\mathrm{E}$ and $\mathrm{F}$ ). However, the
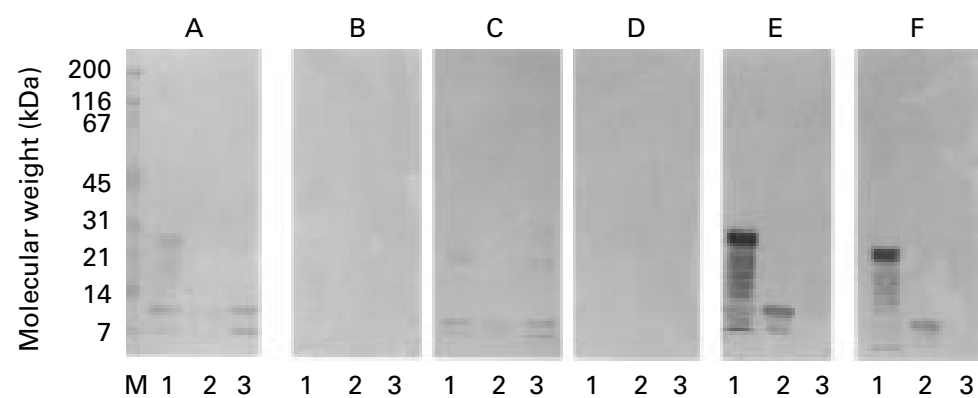

Figure 5 Effect of pepsin digestion on the binding of heat aggregated IgG and of antihistone antibodies to histone as determined by western blots. Proteins on the membrane were prestained molecular weight standards (lane M); a mix of all histone proteins (lane 1); H2A and H2B (lane 2); H3 and H4 (lane 3). The different panels were reacted with different primary reagents: heated normal serum (panel $A$ ); heated normal serum subjected to pepsin digestion (panel B); RA serum (specimen R27) (panel $C$ ); $R A$ serum subjected to pepsin digestion (panel D); serum containing antihistone antibody (spiked specimen HS-1) (panel E); and serum containing antihistone antibody subjected to pepsin digestion (panel F).

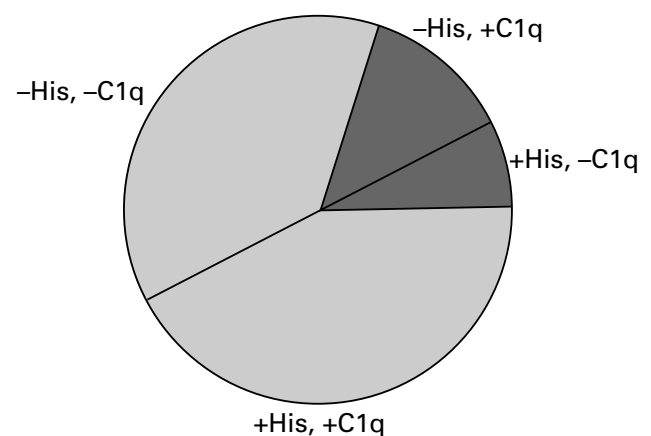

Figure 6 Proportion of $40 \mathrm{RA}$ serum samples with IgG that reacted with C1q or with histone, or both in ELISA. The darker zones represent discrepant specimens; the lighter overlap zones represent the samples positive or negative for both C1q and histone.

histone-specific serum did not react visibly with $\mathrm{H} 3$ and $\mathrm{H} 4$ owing to its relatively narrow antibody specificity, whereas the aggregated IgG reacted (fig 5, panels A, C, and E, lane 3). Moreover, both the histone-specific serum and the aggregated IgG showed weak reactions with the minor contaminants seen on the polyacrylamide gel electrophoresis (most likely fragmented H1). At the same time, the controls, non-heated normal serum, showed no reaction with histone, whether it was subjected to pepsin digestion or not (data not shown). Thus the non-cognate binding of IgG to histone on ELISA and western blot is dependent on its Fc portion.

RELATION BETWEEN THE PRESENCE OF IMMUNE COMPLEXES AND HISTONE BINDING ACTIVITY IN RA SERUM SAMPLES

C1q binding was determined in $20 \mathrm{RA}$ serum samples that showed histone binding activity and in 20 RA samples that did not. Seventeen of the 20 histone positive sera $(85 \%)$ and only five of the 20 negative sera $(25 \%)$ were positive for the presence of CICs by C1q binding (fig $6)$, a significant difference $\left(p<0.001, \chi^{2}\right)$. The difference was also significant when $\mathrm{A}_{405}$ values were considered ( $\mathrm{p}=0.016$, KolmogorovSmirnov). In addition, there was an overall good agreement between the presence of CICs detected by $\mathrm{C} 1 \mathrm{q}$ binding and histone binding $(\kappa=0.6)$. Moreover, the heat aggregated normal serum was also positive by the $\mathrm{C} 1 \mathrm{q}$ binding test, whereas serum containing IgG antihistone antibodies was within normal limits. Thus an agreement was shown between the histone binding activity of RF and the presence of CICs containing IgG in RA sera.

\section{Discussion}

Evidence presented here strongly suggests that the binding of $\mathrm{RF}$ in patients with $\mathrm{RA}$ to histone is non-cognate. Rather, CICs or aggregated IgG attachment to histone on the solid phase provide the antigen for the binding of RF. The evidence is based first on the demonstration that aggregated IgG, a model for immune complexes, ${ }^{12}{ }^{13}$ attaches to histone and generates the antigenic substrate for the RF. Additional support was obtained by the similarities between the binding of RF to histone and the binding of aggregated IgG. 
Unlike cognate binding, both were resistant to free histone competition and were sensitive to pepsin digestion.

The observation that the serum immunoglobulin of a relatively large proportion of patients with RA binds to histones on the solid phase (fig 1) confirmed previous reports ${ }^{5}{ }^{14-16}$ (11-80\%, depending on the detection method, substrate, and patient population). This binding was interpreted as cognate, ${ }^{15}{ }^{16}$ mainly the result of a cross reaction of RF with histone. ${ }^{6-8}$ The cognate recognition relied mainly on experiments with monoclonal $\operatorname{IgM} \mathrm{RF}$, which might be the exception rather than the rule. However, in patients with RA, cognate recognition of histone appeared unlikely (tables 3 and 4). The ability of aggregated IgG to bind to histone suggested that the binding of RF may be indirect, the result of immune complexes or IgG aggregates that first attach to histone and form a solid phase-bound antigen for RF. This possibility is strongly supported by three experiments. Firstly, the heating of serum containing $\mathrm{RF}$ resulted in a significantly increased binding of $\operatorname{IgM}$ to histone coated wells (fig 2). This increased binding of $\operatorname{IgM}$ was not likely to be the result of higher levels of $\operatorname{IgM}$ in RA serum as the difference between IgM levels in blood bank donors and patients with RA is not significant. ${ }^{17}$ Secondly, IgM from RA sera bound much better to histone coated plates pretreated with serum containing aggregated IgG than to histone coated plates pretreated with non-heated human serum (fig 3, table 2). Thirdly, addition of heated IgG to RA sera with low level "histone binding" resulted in a significant increase in the binding of $\operatorname{Ig} M \mathrm{RF}$ to the histone coated wells (fig 4). Moreover, the amount of binding induced by the addition of aggregated IgG to the RA serum was similar to that seen with some RA sera (fig 1). However, the order of assembly of the reactants in RA sera tested for binding to histone is not specified by our experiments with RA sera. Either RF reacted with CICs and the entire complex attached to histone, or CICs first bound to histone and then attracted the RF. Both or either of these mechanisms are possible.

The effect of pepsin digestion strongly supports our conclusion that histone binds aggregated IgG or CICs, or both, from RA patient serum: the attachment of RF is only a consequence of this binding. We have previously shown that pepsin digestion of serum immunoglobulin does not affect the detection of $\operatorname{IgG}$ and $\operatorname{IgA} \mathrm{RF}^{9}$ for two main reasons. Firstly, IgA is resistant to digestion and, secondly, the $\mathrm{F}\left(\mathrm{ab} \mathrm{b}^{\prime}\right)_{2}$ generated from IgG RF retains binding function to rabbit IgG coated wells. Moreover, the anti-F( $\left(\mathrm{b}^{\prime}\right)_{2}$ enzyme conjugate reacts only with IgG $\mathrm{F}\left(\mathrm{ab}^{\prime}\right)_{2}$ but not with IgA RF on the solid phase, probably the result of steric hindrance of the IgA light chains. ${ }^{9}$ If the binding of RF of IgG and IgA was cognate, as their binding to rabbit $\operatorname{IgG},{ }^{9}$ their binding to histone coated plates should not have been affected by pepsin digestion. However, IgG binding and IgA binding from RA sera were abolished by pepsin digestion (table 3, fig 5).
Obviously, since IgM RF was also destroyed by pepsin, no conclusion could be drawn from this experiment about IgM RF. Therefore, competitive inhibition experiments were required for IgM RF.

Antigen competition experiments showed that a cognate interaction of histone with RF of $\operatorname{IgM}, \operatorname{IgG}$, or IgA isotype was unlikely. Whereas the cognate binding of antihistone antibodies to histone was essentially abolished (about $90 \%$ inhibition) by the presence of free histone, the binding of either aggregated IgG or the immunoglobulin in RA sera was only slightly inhibited (table 4, fig 5). It is likely that the need for IgG aggregates, which can interact with multiple histone molecules simultaneously, makes their avid binding highly dependent on solid phase histone. This is analogous to the interaction of an array of adhesion molecules to their ligands or to the attachment of $\mathrm{C} 1 \mathrm{q}$ to aggregated IgG.

In this study the level of "histone binding" by IgM, IgG, or IgA varied widely between patients with RA (fig 1). Our interpretation of the cause of this variability may explain some of the findings in Felty's syndrome associated with RA. Indeed, in Felty's syndrome, a pathogenic role for CICs has been strongly suggested. ${ }^{18}$ Coincidentally, a relatively high frequency of antihistone antibodies detected by ELISA (IgM in $33 \%$ of patients, or IgG in $77 \%$ ), which varies with disease activity, has been described in this syndrome. ${ }^{14}{ }^{16}$ Possibly, what was detected by ELISA as an antihistone antibody reaction was a reflection of the simultaneous presence of immune complexes ${ }^{19} 20$ (fig 6) and RF. However, because the agreement between histone binding activity of RA sera and detection of CICs by the C1q binding technique was not perfect, another hypothesis can be put forward. Aggregation or binding to an antigen induced conformational changes in the IgG molecules. Thus one may suggest that, in addition to aggregated IgG and immune complexes binding to solid phase histone, conformationally altered IgG molecules also bind to histone and subsequently attract RF. The presence of these altered immunoglobulinsfor instance agalactosyl IgG naturally occurring in some patients with $\mathrm{RA},{ }^{21}$ supports this speculation.

The binding of aggregated IgG to histone and subsequent binding of IgG RF to the aggregates, as shown here (fig 3 and 4; table 2) may also explain the report of an increase in the antihistone binding activity of IgG when IgG was separated from RA patient serum; that is, some of the IgG becomes aggregated during the process of isolation. The effect of IgG separation was attributed to the presence of an inhibitor or competitor in the serum. ${ }^{22}$ However, it has also been reported that the RF with histone binding activity was produced in tissue culture from mouse hybridomas, ${ }^{7}$ suggesting that some IgM RF molecules may indeed react with histone. Possibly, those RF molecules interacted in a non-cognate manner with the histone on the solid phase as competition with soluble histone for the binding to solid phase histone was ineffective. ${ }^{7}$ It is also possible that 
the monoclonal antibody had an alteration in structure that promoted the formation of aggregates large enough to bind to solid phase histone.

It has been reported that a large proportion of patients with chronic liver disease (43-50\%) have antihistone antibody reactivity. ${ }^{23}$ However, these patients also have RF and cryoglobulins $^{2425}$ and, therefore, it is possible that their antihistone "antibodies" were the result of an artefact of attachment of CICs or cryoglobulins to histone.

The observations described here suggest a need for re-evaluation of the significance of the presence of antihistone antibodies in patient sera. CICs that bind histone, which have long been considered, erroneously, to be IgG antihistone antibodies, have been detected in most patients with idiopathic systemic lupus erythematosus (unpublished data). Also, histone binds to collagen type IV (and heparan sulphate proteoglycan) in the basement membrane ${ }^{26}{ }^{27}$; a strong structural similarity exists between collagen type IV of the basement membranes and collagen type II of the cartilage, suggesting that the relation between histone, immune complexes, and RF in the joint fluids may have consequences for the inflammatory process. Our results suggest that a new test for the detection of CICs may be developed and that solid phase histone may be used to remove CICs from plasma in apheresis systems more selectively than it is now done with the help of staphylococcal protein A. ${ }^{28}$

This work was supported in part by a grant from TheraTest Laboratories, Chicago, IL. The authors thank Dr W Carey Hanly for her critical reading of the manuscript.

1 Olins DE, Olins AL. Nucleosomes: the structural quantum in chromosomes. American Scientist 1978;66:704-9.

2 Aktipis S. DNA: the replicative process and repair. In: Devlin TM, ed. Textbook of clinical biochemistry with clinical correlation. Chichester: Wiley, 1992:637-41.

3 Tax WJ, Kramers C, van Bruggen MC, Berden JH. Apoptosis, nucleosomes, and nephritis in systemic lupus erythematosus [editorial]. Kidney Int 1995;48:666-73.

4 Cabrespines A, Laderach D, Lebosse C, Bach JF, Koutouzov S. Isolation and characterization of apoptotic nucleosomes, free and complexed with lupus autoantibody generated during hybridoma B-cell apoptosis. J Autoimgenerated during hyb

5 Agnello V, Arbetter A, Ibanez de Kasep G, Powell R, Tan $\mathrm{EM}$, Joslin F. Evidence for a subset of rheumatoid factors that cross-react with DNA-histone and have a distinct cross-idiotype. J Exp Med 1980;151:1514-27.

6 Hannestad K, Rekvig OP, Husebekk A. Cross-reacting rheumatoid factors and lupus erythematosus (LE)-factors. Springer Seminars in Immunopathology 1981;4:133-60.

7 Rubin RL, Balderas RS, Tan EM, Dixon FJ, Theofilopoulos AN. Multiple autoantigen binding capabilities of mouse monoclonal antibodies selected for rheumatoid factor activity. J Exp Med 1984;159:1429-40.

8 Rubin RL. Antihistone antibodies. In: Lahita RG, ed. Systemic lupus erythematosus. San Diego: Academic Press, 1999:227-45

9 Swedler W, Wallman J, Froelich CJ, Teodorescu M. Routine measurement of $\operatorname{IgM}, \operatorname{IgG}$, and $\operatorname{IgA}$ rheumatoid factors: high sensitivity, specificity and predictive value for rheumatoid arthritis. J Rheumatol 1997;24:1037-44

10 Giclas PC. Complement. In: Coligan JE, Kruisbeek AM, Margulies DH, Shevach EM, Strobber W, eds. Current protocols in immunology. New York: Wiley, 1994:13.0.313.1.26.

11 Campbell RC. Statistics for biologists. 2nd ed. Cambridge: Cambridge University Press, 1979.

12 Baumann MA, Anderson BE. An immune complex selective affinity matrix utilizing a synthetic peptide. J Biol Chem 1990;265:18414-22

13 Van Der Giessen M, The TH. Characterization of the soluble immune complexes that are detected by three different techniques. Clin Immunol Immunopathol 1986;38:24455.

14 Cohen MG, Webb J. Antihistone antibodies in rheumatoid arthritis and Felty's syndrome. Arthritis Rheum 1989;32: 1319-24.

15 Pasquali JL, Azerad G, Martin T, Muller S. The double reactivity of a human monoclonal rheumatoid factor to IgG reactivity of a human monoclonal rheumatoid factor to IgG
and histones is related to distinct binding sites. Eur J Immunol 1988;18:1127-30.

16 Muzellec Y, Le Goff P, Jouquan J, Fauquert P, Muller S, Youinou, P. Antibodies to histones in rheumatoid arthritis. Diagnostic Clinical Immunology 1988;5:326-31.

17 Adhya S, Chakraborty G, Hajra B, Bhattacharya S, Sikdar $\mathrm{PK}$, Sinha S, et al. Serology and immunoglobulin profile in rheumatoid arthritis. Indian J Pathol Microbiol 1998;41: 43-7.

18 de Bandt M, Meyer O. Manifestations extra-articulaires de la polyarthrite rhumatoide. La Revue du Praticien (Paris) 1997;47:2012-16.

19 Andreis M, Hurd ER, LoSpalluto J, Ziff M. Comparison of the presence of immune complexes in Felty's syndrome and rheumatoid arthritis. Arthritis Rheum 1978;21:31015 .

20 Hurd ER, Chubick A, Jasin HE, Ziff M. Increased C1q binding immune complexes in Felty's syndrome: comparison with uncomplicated rheumatoid arthritis. Arthritis Rheum 1979;22:697-702.

21 Axford JS, Sumar N, Alavi A, Isenberg DA, Young A, Bodman KB, et al. Changes in normal glycosylation mechanisms in autoimmune rheumatic diseases. J Clin Invest 1992;89:1021-31.

22 Bustos A, Boimorto R, Subiza JL, Pereira LF, Marco M, Figueredo MA, et al. Inhibition of histone/anti-histone reactivity by histone-binding serum components; differen-
tial effect on anti-H1 versus anti-H2B antibodies. Clin Exp tial effect on anti-H1 versus an

23 Konikoff F, Swissa M, Shoenfeld Y. Autoantibodies to histones and their subfractions in chronic liver diseases. Clin Immunol Immunopathol 1989;51:77-82.

24 Fornasieri A, d'Amico G. Type II mixed cryoglobulinemia, hepatitis C infection, and glomerulonephritis. Nephrol Dial Transplant 1996;II(suppl 4):25-30.

25 Csepregi A, Nemesanszky E, Bely M. Kryoglobulinamie und chronische Lebererkrankungen. Z Gastroenterol 1998;36:391-401.

26 Termaat RM, Brinkman K, van Gompel F, van den Heuvel LPWJ, Veerkamp JH, Smeenk RJT, et al. Cross-reactivity of monoclonal anti-DNA antibodies with heparan-sulfate is mediated via bound DNA histone complexes. J Autoimmun 1990;3:531-45.

27 Bernstein KA, Di Valerio R, Lefkowith JB. Glomerular binding activity in MRL lpr serum consists of antibodies that bind to a DNA/histone/type IV collagen complex. J mmunol 1995;154:2424-33.

28 Felson D, Furst D, LaValley M, Gendreau M. Results of a randomized double blind trial of the Prosorba ${ }^{\circledR}$ column for treatment of severe rheumatoid arthritis [abstract]. Arthritis Rheum 1998;41(suppl 9):S364. 